\title{
Inclusáo Escolar e os Desafios para a Formação de Professores ${ }^{1}$
}

\author{
Tereza Cristina de CARVALHO ${ }^{2}$
}

MENDES, Enicéia, Gonçalves; CIA, Fabiana; CABRAL, Leonardo, S. A. (Org.). Inclusão Escolar e os Desafios para a Formação de Professores em Educação Especial.São Carlos: Marquezine\& Manzini, Marília: ABPEE, 2015.

A Educação Especial em todos seus âmbitos tem sido foco de discussóes e pesquisas em todo Brasil com o intuito de compreender, analisar ou propor mudanças, pensando no público-alvo da Educação Especial e na formação continuada de professores para melhor atender esse público em específico.

A partir do "Programa de Implantação da Sala de Recursos Multifuncionais", lançado pela Secretaria de Educação Especial/MEC no ano de 2005, o Grupo de Pesquisa sobre Formação de Recurso Humanos (GP - Foreesp) da Universidade Federal de São Carlos criou em 2010 o Observatório Nacional de Educação Especial (Oneesp) para desenvolver pesquisas a respeito das políticas e práticas voltadas para a inclusão escolar.

Para compreender melhor como tem sido direcionada a temática, foi proposto um projeto com o intuito de investigar os limites e possibilidades dos serviços oferecidos pela Sala de Recursos Multifuncionais (SRM). Dentre os três eixos que seriam avaliados, a formação inicial e continuada de professores que atuam nas SRM foi um deles.

O projeto tomou maiores proporções e, em 2011, constituída uma rede nacional. Dessa maneira, a partir de 2011 foram realizados encontros com o objetivo de socializar conhecimentos, planejar o direcionamento dos estudos, analisar em que patamar cada estudo se encontrava, apresentar os primeiros resultados, e, finalmente, divulgar os estudos finalizados. Assim, a Oneesp publicou o primeiro livro em 2014 e, em 2015, organizou outros três livros, completando a série. O livro Inclusão Escolar e os Desafios para a Formação de Professores em Educação Especial, é o terceiro dessa série e apresenta os resultados dos estudos de 33 municípios.

O livro foi composto por vinte e quatro capítulos e dividido em cinco partes. A primeira, intitulada de Múltiplos olhares: Regiāo Centro-Oeste: Goiás e Mato Grosso do Sul, é composta por dois capítulos e apresenta, em seu primeiro capítulo, os principais resultados a respeito do direcionamento da formação inicial e continuada dessa região e sobre a identidade e os papéis dos profissionais que atuam no Atendimento Educacional Especializado (AEE) e na SRM. O Capítulo 2 apresenta o perfil de formação, tempo de experiência, situação funcional

\footnotetext{
${ }^{1}$ http://dx.doi.org/10.1590/S1413-65382216000200012

${ }^{2}$ Pedagoga, Mestre em Educação e Doutoranda em Educação Especial pela UNESP (Campus de Marília). cristinaiwamoto@hotmail.com
} 
dos professores e a percepção dos mesmos e dos gestores sobre a formação para atuar no AEE e finaliza discutindo sobre os limites e os desafios enfrentados na atuação da SRM.

A segunda parte do livro, Múltiplos olhares: Região Norte: Pará também é composta por dois capítulos e apresenta, no terceiro capítulo, as reflexóes dos professores sobre formação inicial e trabalho colaborativo realizado pelos professores da SRM. O quarto capítulo apresenta uma descrição das matrículas do público-alvo da Educação Especial na rede regular de ensino e a estrutura oferecida para o AEE, além de apresentar e discutir as inúmeras perspectivas sobre a formação de professores que participaram do estudo.

A terceira parte do livro, Múltiplos olhares: Região Nordeste: Alagoas, Bahia, Maranhão, Paraiba e Rio Grande do Norte é composta por sete capítulos e apresenta, no quinto capítulo, as perspectivas, possibilidades e os anseios de professores da SRM da rede regular de ensino, além das inquietaçóes desinentes da dissociação entre teoria e prática. O Capítulo 6 analisa os dados sobre a formação de professores que trabalham no AEE nas SRM na perspectiva da inclusão. O sétimo capítulo apresenta os dados referentes à formação inicial e continuada dos docentes e da atuação no AEE. O oitavo capítulo apresenta e discute as perspectivas e desafios da formação docente no contexto da educação especial sob a ótica de cinco dimensóes específicas que interferem na formação dos professores e, consequentemente, em sua atuação. O nono capítulo apresenta as reflexões dos professores a respeito da formação inicial e continuada, demandas da política de inclusão e sobre o papel do professor para atuar nas SRM. O Capítulo 10 contempla as concepçóes dos professores a respeito da formação inicial e continuada e sobre a formação de professores para a atuação na Educação Especial. O décimo primeiro capítulo aponta e discute os dados da investigação relacionada à formação inicial e continuada dos professores da SRM. Enfim, o décimo segundo capítulo encerra essa parte do livro, apresentando a visão dos professores sobre a atuação no AEE, formação de professores para a atuação na SRM, formação continuada e sobre suas próprias formaçóes.

A quarta parte do livro, Múltiplos olhares: Região Sudeste: Espirito Santo, Rio de Janeiro e São Paulo é composta por nove capítulos e apresenta, no Capítulo 13, as discussões a respeito da formação inicial e continuada dos profissionais e sobre a atuação na SRM. O Capítulo 14 apresenta o resultado das discussóes referentes a formação de professores para a inclusão escolar, avaliação dos alunos com necessidades educacionais especiais e organização do ensino nas SRM e classes comuns. O Capítulo 15 apresenta uma análise da formação dos professores, problematizando a suas práticas pedagógicas desenvolvidas na SRM e os impactos que as Políticas Públicas de Inclusão trouxeram para a formação desses professores. O Capítulo 16 apresenta as discussões sobre a formação de professores para a inclusão escolar, avaliação dos alunos com necessidades educacionais especiais e a organização do ensino da SRM e das classes comuns. O Capítulo 17 reúne, sistematiza e analisa a opinião dos professores da SRM e dos gestores a respeito da legislação, confrontando com a literatura científica, os enfrentamentos diários no cotidiano escolar e a relação de suas formações com a realidade atual de implementação das SRM em seus municípios. O Capítulo 18 descreve e analisa os dados obtidos em relação à formação inicial e continuada, importância da formação e sobre a falta de formação. O Capítulo 19 apresenta as discussóes realizadas a partir dos dados do eixo Formação de Professores da SRM, trazendo as discussóes em torno da atuação profissional, função do professor especializado, modelos de trabalho e de formação inicial e continuada. O Capítulo 20 apresenta a sistemati- 
zação das discussões a respeito do percurso que levaram os professores para a área da educação especial, formação inicial, postura dos professores em relação às demandas de alunos na educação básica, atuação dos professores na SRM e seus sentimentos em relação a suas ações, sobre o potencial com a formação que possuem, esclarecimento sobre as políticas públicas e atualização profissional. O Capítulo 21 encerra o ciclo de questóes propostas nessa região e apresenta as discussóes realizadas a respeito das concepçóes de AEE dos professores da SRM a respeito de formação, além de apresentar e analisar os aspectos associados às vantagens e desvantagens de suas próprias práticas pedagógicas.

A quinta parte do livro, Múltiplos olhares: Região Sul: Rio Grande do Sul e Santa Catarina apresenta em seis capítulos. O Capítulo 22 apresenta as oportunidades de formação para a atuação na Educação Especial. Relata também as concepçóes desses profissionais a respeito formação inicial e continuada, a compreensão que possuem sobre o funcionamento do AEE e da SRM e sobre o papel que possuem na educação sob a ótica inclusiva. O Capítulo 23 relata o ponto de vista dos professores a respeito das novas demandas para a formação dos professores, formação inicial e continuada e sobre as competências e papel do professor do AEE. O Capítulo 24 encerra um compilado sobre o perfil do professor que atua no AEE, formação inicial e continuada e sobre a percepção que cada professor possui sobre o próprio trabalho na SRM.

Em suma, Inclusão Escolar e os Desafios para a Formação de Professores em Educação Especial é um livro que apresenta um panorama geral dos resultados das pesquisas realizadas em 33 municípios, de cinco regióes brasileiras, a respeito do eixo - Formação de Professores para a atuação nas Salas de Recursos Multifuncionais, abrangendo inúmeros contextos e concepçóes e apontando um norte sobre a temática proposta. 
CARVALHO, T. C. 